\title{
5. List of 105 Original Articles and Reviews Produced in This Project
}

1. Agatsuma T, Ito M. Isozyme study of Onchocerca volvulus and Onchocerca gutturosa in Guatemala. J Parasitol 1985; 71: 370-373.

2. Agatsuma T, Uemoto K, Ochoa JO. Biochemical genetics of blackfly isozymes. I. Isozyme variation among three species, Simulium ochraceum, S. metallicum and $S$. horacioi from Guatemala. Jpn J Sanit Zool 1986; 37: 1-9.

3. Akiyama T, Ushijima N, Anan S, Nonaka S, Yoshida H, Zea FGE. Immunological studies of onchocerciasis in Guatemala. J Dermatol 1981; 8: 43-46.

4. Aoki Y, Recinos MM, Hashiguchi Y. Life span and distribution of Onchocerca volvulus microfilariae in mice. J Parasitol 1980; 66: 797-801.

5. Aoki Y, Sakamoto M, Yoshimura T, Tada I, Recinos MM, Figueroa MH. Onchocercomas in Guatemala, with special reference to appearance of new nodules and parasite content. Am J Trop Med Hyg 1983; 32: 741-746.

6. Fukumoto S, Ito M, Kamiya M, Flores FZ. Diagnostic studies of human onchocerciasis in Guatemala; Investigation of incubation method for skin biopsy. Jpn J Parasitol 1983; 32(2): 88.

7. Hashiguchi Y, Kawabata M, Ito S, Recinos CMM. Limited fly load and development of Onchocerca volvulus microfilariae in Guatemalan Simulium ochraceum. J Helminthol 1981; 55: 189-196.

8. Hashiguchi Y, Kawabata M, Takaoka M, Flores CO. Microfilarial density in Guatemalan onchocerciasis patient's skin with special reference to the hourly intake by Simulium ochraceum. Jpn J Trop Med Hyg 1983; 11: 2533.

9. Hashiguchi Y, Kawabata M, Takaoka M, Yoshimura T, Recinos CMM. The long-term absence of onchocerciasis in an area where the vectors, Simulium spp., are found. Trans Royal Soc Trop Med Hyg 1981; 75: 901.

10. Hashiguchi Y, Kawabata M, Tanaka I, Okazawa T, Flores $\mathrm{CO}$, Recinos MM. Seasonal variation in the microfilarial skin density of Onchocerca volvulus and in the biting activity of Simulium spp. in Guatemala. Trans Royal Soc Trop Med Hyg 1981; 75: 839-845.

11. Hashiguchi Y, Kawabata M, Zea FG, Recinos CMM, Flores CO. The use of an Onchocerca volvulus microfilarial antigen skin test in an epidemiological survey of onchocerciasis in Guatemala. Trans Royal Soc Trop Med Hyg 1979; 73: 543-548.

12. Hashiguchi Y, Tada I, Ochoa AJO, Recinos CMM, Molina PA. Bovine and equine onchocerciasis in Guatemala, especially in San Vicente Pacaya. J Parasitol 1981; 67: 286-287.

13. Hashiguchi Y, Tada I, Flores CO, Takaoka H. Diurnal biting activity of four zoophilic species of Simulium in an area endemic for human onchocerciasis in Guatemala. Jpn J Trop Med Hyg 1982; 10: 239-244.

14. Hirai H, Sakaguchi Y, Tada I. Chromosomes of Onchocerca volvulus and O. gutturosa. Z Parasitenkd 1985; 71: 135-139.

15. Hirai H, Tada I, Takahashi H, Nwoke BEB, Ufomadu GO. Chromosomes of Onchocerca volvulus (Spirurida: Onchocercidae): A comparative study between Nigeria and Guatemala. J Helminthol 1987; 61: 43-46.

16. Ikeda T, Aoki Y, Tada I, Recinos CMM, Ochoa AJO, Molina PA. A sero-epidemiological study of onchocerciasis with the indirect hemagglutination test. J Parasitol 1979; 65: 855-861.

17. Ikeda T, Tada I, Aoki Y. The indirect hemagglutination test for onchocerciasis performed with blood collected on filter paper. J Parasitol 1978; 64: 786-789.

18. Ishida N, Nakayasu K, Mendez GEA, Yamada H. Aspects of onchocercal punctate opacities observed in Guatemala. 1., Folia Ophthalmol Jpn 1981; 32: 2145-2151.

19. Ito M, Kamiya M, Lujan TA. Fluctuation of ELISA and skin biopsy results in individual inhabitants re-examined after several months in the endemic area of Guatemalan onchocerciasis. Ann Trop Med Parasitol 1984; 78: 553 555 .

20. Ito M, Lujan TA, Fukumoto S, Kamiya M. Enzymelinked immunosorbent assay (ELISA) as a diagnostic tool for Guatemalan onchocerciasis using a bovine filaria (Onchocerca gutturosa) antigen and blood samples collected on filter paper. Jpn J Vet Res 1983; 31: 141-150.

21. Ito S, Tanaka I, Ochoa OA. Comparative studies on the affinities of two blackflies, Simulium metallicum and $S$. ochraceum for the larvae of Onchocerca volvulus in Guatemala. Jpn J Sanit Zool 1980; 31: 261-267.

22. Kamimura K, Suzuki T, Okazawa T, Inaoka T, Ochoa OA. Effect of temefos against the blackfly larvae in stream tests in Guatemala. Jpn J Sanit Zool 1985; 36: 189-195.

23. Kamiya M, Fukumoto S, Ito M, Lujan A. A simplified indirect haemagglutination test (IHA) for the diagnosis of onchocerciasis. Jpn J Vet Res 1983; 45(Suppl): 105.

24. Kawabata M, Hashiguchi Y, Zea FG. Distribution pattern of microfilariae in relation to sex and age in Guatemalan onchocerciasis. Trans Royal Soc Trop Med Hyg 1983; 77: 215-216.

25. Kawabata M, Hashiguchi Y, Zea FG, Yamada H, Aoki Y, Tada I, Recinos CMM, Flores CO. The distribution of microfilariae in the skin of Guatemalan onchocerciasis patients: an evaluation of diagnostic potentials. J Helminthol 1980; 54: 183-190.

26. Kawabata M, Izui S, Anan S, Kondo S, Fukumoto S, Zea 
FG, Kobayakawa T. Circulating immune complexes and their possible relevance to other immunological parameters in Guatemalan onchocerciasis. Int Archs Allergy Appl Immun 1983; 72: 128-133.

27. Kawabata M, Zea FG, Izui S, Kobayakawa T. IgM Rheumatoid factors in Guatemalan onchocerciasis. Trans Royal Soc Trop Med Hyg 1984; 78: 356-358.

28. Korenaga M, Tada I, Hashiguchi Y, Takaoka H, Baba M, Castro JC, Zea FGE. Detection of specific IgE antibodies in Guatemalan onchocerciasis by enzyme-linked immunosorbent assay (ELISA). Jpn J Parasitol 1986; 35: 295301 .

29. Korenaga M, Tada I, Mimori T, Sakamoto M, Lujan TA, Zea FGE, Castro JC, Yarzabal L. Enzyme-linked immunosorbent assay (ELISA) in the detection of IgG antibodies in onchocerciasis using blood collected on filter paper. Jpn J Parasitol 1983; 32: 347-355.

30. Matsuo K. Aplicacion de larvicida solido de temefos en el control de la oncocercosis en Guatemala. Bol Sanit Panamer 1983; 95: 412-417.

31. Matsuo K, Okazawa T, Onishi O, Ochoa AJO. Maintenance of the adults of Guatemalan blackfly, Simulium ochraceum, in the laboratory. Jpn J Sanit Zool 1978; 29: 251-254.

32. Matsuo K, Ochoa AJO. Scanning electron microscopic studies on Guatemalan black flies. I. Abdominal dorsal hairs of larvae of 6 species. Jpn J Sanit Zool 1979; 30: 329-333.

33. Matsuo K, Okazawa T, Onishi O, Ochoa AJO. Experimental observation of developmental period of Onchocerca volvulus in blackfly, Simulium ochraceum. Jpn J Parasitol 1980; 29: 13-17.

34. Mimori T. A histological study of the skin and nodule during the course of diethylcarbamazine treatment in onchocerciasis. Jpn J Parasitol 1985; 34: 301-309.

35. Mimori T, Tada I, Shiwaku K, Ufomadu GO, Nwoke BFB. A biometric study of Onchocerca volvulus microfilariae from Nigeria using the nuclear counting method. Z Parasitenkd 1986; 72: 835-836.

36. Miura M, Sakamoto M, Aoki Y. Scanning electron microscopy of Onchocerca volvulus mirofilaria from Guatemala. Trop Med 1985; 27: 141-146.

37. Nakamura Y, Yamagata Y, Takaoka H, Takahashi M, Ochoa OA, Molina PA, Takahashi H. A control trial of the vector of onchocerciasis, Simulium ochraceum (Diptera: Simuliidae) in the Lavaderos Valley, Guatemala. Jpn J Sanit Zool 1981; 32: 51-58.

38. Nakayasu K, Ishida N, Mendez G, Yamada EAH, Matsuki T. Ocular onchocerciasis in Guatemala-Follow-up survey of the clinical findings of anterior ocular lesions. Folia Ophthalmol Jpn 1982; 33: 1123-1130.

39. Nogami S, Hayashi Y, Korenaga M, Tada I, Tanaka H. Monoclonal antibodies specific for Onchocerca volvulus as determined by immunofluorescence. Internat J Parasitol 1988; 18: 503-507.

40. Nogami S, Hayashi Y, Tanaka M, Korenaga M, Tada I, Tanaka H. Antigenic similarity of Onchocerca volvulus to other helminths examined by monoclonal antibodies against $O$. volvulus. Jpn J Exp Med 1986; 56: 177-183.

41. Nonaka S, Hashiguchi Y, Kawabata M, Aoki Y, Tada I, Figueroa MH, Zea FG. Dermatological survey of onchocerciasis in Guatemala. J Dermatol 1980; 7: 61-70.

42. Nonaka S, Yoshimura T, Sakamoto M, Zea FG. Dermatological survey of onchocerciasis in Guatemala. II. Relationship between the prevalence rate of cutaneous changes and that of onchocerciasis. J Dermatol 1983; 10: 439-445.

43. Ochoa AO. Studies on the anthropophilic blackfly species in Guatemala, with special reference to the transmission of onchocerciasis in the south-eastern endemic area. Jpn J Sanit Zool 1982; 33: 129-138.

44. Ochoa AJO, Takaoka H. A new blackfly species of Mayacnephia from Guatemala (Diptera: Simuliidae). Jpn J Trop Med Hyg 1993; 21: 5-7.

45. Ogata K. Preliminary report of Japan-Guatemala onchocerciasis control pilot project. In Laird M, ed. Blackflies - the future for biological methods in integrated control. 1981. pp 105-115.

46. Okazawa T, Onishi O. Description of a new species of Simulium (Simulium) Latrelle and redescription of Simulium (Simulium) metallicum Bellradi from Guatemala (Diptera: Simuliidae). Jpn J Sanit Zool 1980; 31: 167-179.

47. Okazawa T, Takahashi H. Blackflies (Diptera: Simuliidae) in highland streams in Guatemala, with special reference to the seasonal prevalence of immature stages and voltinism. Jpn J Sanit Zool 1981; 32: 301-308.

48. Okazawa T, Nodasaka Y. Morphological observations on the first and the last-instar larvae of the genus Gigantodax (Diptera: Simuliidae). Jpn J Sanit Zool 1982; 33: 95-103.

49. Okazawa T, Yamagata Y. Breeding streams of Mayacnephia aguirrei (Diptera: Simuliidae). Jpn J Sanit Zool 1985; 36: 349-351.

50. Poinar Jr GO, Takaoka H. Isomermis benevolus sp. $\mathrm{n}$. (Mermithidae, Nematoda), a parasite of Simulium metallicum (Diptera: Simuliidae) in Guatemala. Jpn J Sanit Zool 1979; 30: 305-307.

51. Poinar Jr GO, Takaoka H. Three new mermithids (Nematoda) from Guatemalan blackflies (diptera: Simuliidae). Syst Parasit 1981; 3: 13-19.

52. Procunier WS, Hirai H. The chromosomes of Onchocerca volvulus. Parasitol Today 1986; 2: 307-309.

53. Sakamoto M, Zea FG. The change of blood picture of patients with onchocerciasis following administration of diethylcarbamazine. Trop Med 1983; 25: 47-50.

54. Suzuki T. A guidebook for Guatemalan onchocerciasis (Robles disease) - with special reference to vector control. Tokyo: JICA; 1983.

55. Suzuki T. Manual of onchocerciasis (Robles disease) control in Guatemala. Tokyo: JICA; 1983.

56. Suzuki T. Glossary for technical terms on onchocerciasis (Robles disease) in Guatemala. Tokyo: JICA; 1983.

57. Suzuki T, Mizutani K. Onchocerciasis vector control in Guatemala. Jpn J Sanit Zool 1992; 43: 273-286. 
58. Suzuki T, Takaoka H, Tada I. Distribution, bionomics and control of vector of human onchocerciasis in Guatemala. WHO, ONCHO/EC/WP/ 1986; 86: 21.

59. Suzuki T, Mizutani K. Onchocerciasis control in Guatemala. Med Entomol Zool 1992; 43: 273-286.

60. Tabaru Y, Nakamura Y, Ochoa AJO, Molina PA, Takahashi H. Preliminary field study on larvicide formulations for onchocerciasis vector control in Guatemala. Jpn J Sanit Zool 1982; 33: 369-377.

61. Tada I. Comparison of onchocerciasis between Central and South Americas: A tragic tropical rainforest. Fukuoka Acta Med 1993; 84(2): 43-46.

62. Tada I. Onchocerciasis. Progress of Medical Parasitology in Japan. Tokyo: Meguro Parasitological Museum; 2003; 8: $557-570$

63. Tada I. International medical Cooperation: General view. Progress of Medical Parasitology in Japan. Tokyo: Meguro Parasitological Museum; 2003; 8: 585-590.

64. Tada I. Japanese medical aid programs in Latin America. Progress of Medical Parasitology in Japan. Tokyo: Meguro Parasitological Museum; 2003: 8: 631-645.

65. Tada I, Aoki Y, Rimola CE, Ikeda T, Matsuo K, Ochoa AJO, Recinos CM, Sato S, Godoy BHA, Orellana JJC, Takahashi H. Onchocerciasis in San Vicente Pacaya, Guatemala. WHO/ONCHO/77.140, 1-9.

66. Tada I, Aoki Y, Rimola CE, Ikeda T, Matsuo K, Ochoa AJO, Recinos CM, Sato S, Godoy BHA, Orellana JJC, Takahashi H. Onchocerciasis in San Vicente Pacaya, Guatemala. Am J Trop Med Hyg 1979; 28: 67-71.

67. Tada I, Figueroa MH. The density of Onchocerca volvulus microfilariae in the skin at different times of the day in Guatemala. Jpn J Parasitol 1974; 23: 220-225.

68. Tada I, Figueroa MH, Takaoka H. Epidemiological studies on Robles' disease (American onchocerciasis) in Guatemala. Jpn J Trop Med Hyg 1974; 2: 35-51.

69. Tada I, Korenaga M, Mimori T, Sakamoto M, Yoshimura T, Recinos CM, Flores OF, Lujan TA, Ochoa AJO, Castro JC, Zea FG. A comparative study of several diagnostic measures applied in Guatemalan onchocerciasis. Jpn J Parasitol 1985; 34: 261-271.

70. Tada I, Korenaga M, Shiwaku K, Ogunba EO, Ufomadu GO, Nwoke BEB. Specific serodiagnosis with adult Onchocerca volvulus antigen in an enzyme-linked imunosorbent assay. Am J Trop Med Hyg 1987; 36: 383-386.

71. Tada I, Mimori T, Nonaka S, Figueroa MH. Mazzotti reaction: Clinical and histological observation of onchocerciasis cases tested in Guatemala. Jpn J Parasitol 1981; 30: 501-507.

72. Tada I, Mimori T, Sakaguchi Y, Kusano M, Hashiguchi Y, Recinos CM. The use of aceto-orcein-stained squash preparations for enumeration of nuclei in microfilariae of various filarial parasites. Am J Trop Med Hyg 1981; 30: 593-597.

73. Takaoka H. Pathogens of blackfly larvae in Guatemala and their influence on natural populations of three species of onchocerciasis vectors. Am J Trop Med Hyg 1980; 29: 467-472.
74. Takaoka H. Seasonal occurrence of Simulium ochraceum, the principal vector of Onchocerca volvulus, in the southeastern endemic area of Guatemala. Am J Trop Med Hyg 1981; 30: 1121-1132.

75. Takaoka H. Further studies of pathogens of blackfly larvae in Guatemala. Their influence on natural populations of three species of onchocerciasis vectors. In Laird M, Praeger NY, ed. Biocontrol of medical and veterinary pests. 1981. pp 78-104.

76. Takaoka H. Observations on the bionomics of larval and man-biting female populations of Simulium horacioi, a new potential vector of Onchocerca volvulus in Guatemala. Jpn J Trop Med Hyg 1982; 10: 49-62.

77. Takaoka H. Review on the biology and ecology of adult blackflies in relation to the transmission of onchocerciasis in Guatemala. Jpn J Trop Med Hyg 1982; 10: 1-22.

78. Takaoka H. Pathogens of blackflies in Guatemala and their influence on natural populations of the three onchocerciasis vectors. Jpn J Trop Med Hyg 1992; 20: 251-259.

79. Takaoka H, Hansen KM, Takahashi H, Ochoa JO, Juarez EL. Development of Onchocerca volvulus larvae in Simulium ochraceum at various altitudes in Guatemala with special reference to the ambient temperature. Jpn J Trop Med Hyg 1981; 9: 187-197.

80. Takaoka H, Ochoa JO, Takahashi M, Takahashi H. Evaluation of temephos as a larvicide against Simulium ochraceum (Diptera: Simuliidae) in Guatemala. J Med Entomol 1981; 18: 145-152.

81. Takaoka H, Ochoa JO, Juarez EL, Hansen KM. Effects of temperature on development of Onchocerca volvulus in Simulium ochraceum and longevity of the simuliid vector. J Parasitol 1982; 68: 478-483.

82. Takaoka H, Takahashi H. A new species of blackfly (Diptera: Simuliidae) from upland areas of Guatemala. J Med Entomol 1982; 19: 63-67.

83. Takaoka H, Suzuki T. Epidemiology and control of Guatemalan onchocerciasis. In Kim KC, Meritt RW, ed. Blackflies: Ecology, population management and annotated world list. The Pennsylvania State University Press; 1987. pp 374-386.

84. Takaoka M, Lujan TA, Hashiguchi Y, Kawabata M, Ito Y, Hayashi S. Evaluation of the double diffusion test for the serodiagnosis of onchocerciasis in Guatemala. Jpn J Parasitol 1983; 32: 451-457.

85. Tanaka I, Hashiguchi Y, Okazawa T, Ochoa AJO, Tada I. Duration of blood feeding of Simulium ochraceum in relation to intake of Onchocerca volvulus microfilariae. Jpn J Sanit Zool 1980; 31: 209-214.

86. Umino T, Suzuki T, Ochoa AJO. Insecticide studies in vector control of Guatemalan onchocerciasis. 1. Short carry of temefos in minute streamlets. Jpn J Sanit Zool 1983; 34: 213-219.

87. Umino T, Suzuki T, Juarez EL. Insecticide studies in vector control of Guatemalan onchocerciasis. 2. Efficacy of larvicides assessed by simulated tough tests. Jpn J Sanit Zool 1983; 34: 269-277.

88. Umino T, Suzuki T. Insecticide studies in vector control 
of Guatemalan onchocerciasis. 3. Laboratory tests on adsorption of larvicides to soil. Jpn J Sanit Zool 1984; 35: $1-6$.

89. Undeen AH, Takaoka H, Hansen K. A test of Bacillus thuringiensis var. israelensis de Barjac as a larvicide for Simulium ochraceum, the Central American vector of onchocerciasis. Mosquito News 1981; 41: 37-40.

90. Wada Y. Theoretical approach to the epidemiology of onchocerciasis in Guatemala. Jpn J Med Sci Biol 1982; 35: 183-196.

91. Watanabe M, Tanaka I, Okazawa T, Yamagata Y, Ochoa AJO. Notes on the age determination, ovariole changes and gonotrophic cycle of Simulium ochraceum in Guatemala. Jpn J Sanit Zool 1980; 31: 215-222.

92. Yamada H. Onchocerciasis (Robles disease, Riverblindness) in Guatemala and Ghana-Clinical features and epidemiological research-Folia. Ophthalmol Jpn 1978; 29: 1817-1837.

93. Yamada H. Fluorescein angiographic findings in ocular onchocerciasis in Guatemala-with reference to findings of ERG of Ghanian patients. Acta Soc Ophthalm Jap 1979; 83: 874-886.

94. Yamada H. Ocular onchocerciasis in Guatemala. Folia Ophthalmol Jpn 1981; 32: 1012-1024.

95. Yamada H, Oikawa T. Ocular onchocerciasis in heavily endemic focus in Guatemala. Folia. Ophthalmol Jpn 1980; 31: 1637-1647.

96. Yamagata Y. Effect of channel slope and stream discharge on the distribution of blackfly larvae in Guatemala. Jpn J Sanit Zool 1984; 35: 293-300.

97. Yamagata Y. Crawling movement of larvae of Mayacnephia aguirrei (Diptera: Simuliidae). Jpn J Sanit Zool 1985; 36: 227-231.

98. Yamagata Y. Movement response of larvae of Simulium ochraceum Walker and S. horacioi Okazawa et Onishi (Diptera: Simuliidae) to water depth and current velocity in a trough. Jpn J Sanit Zool 1986; 37: 11-16.

99. Yamagata Y, Kanayama A. Micro-distribution of Simulium ochraceum Walker (Diptera: Simuliidae) larvae in relation to stream depth and current velocity. Jpn J Sanit Zool 1985; 36: 227-231.

100. Yamagata Y. Seasonal change of discharge rate in streams infested with Simulium ochraceum Walker (Diptera: simuliidae) in Guatemala. Jpn J Sanit Zool 1986; 37: 91-94.

101. Yamagata Y, Okazawa T, Molina PO. Geologic and geomorphological studies on distribution of Simulium ochraceum (Diptera: Simuliidae) larvae in Guatemala. Jpn J Sanit Zool 1984; 35: 95-102.

102. Yamagata Y, Ochoa AJO, Molina PA, Sato H, Uemoto K, Suzuki T. Chemical control of Simulium ochraceum Walker (Dipters: Simuliidae) larvae in an onchocerciasis endemic area of Guatemala. Trop Med Parasit 1987; 38: 205-210.

103. Yanagawa T, Kasagi F, Yoshimura T. A method for estimating incidence rates of onchocerciasis from skin-snip biopsies with consideration of false negatives. Biometrics 1984; 40: 301-311.

104. Yoshimura T, Hashiguchi Y, Kawabata M, Flores COF, Gudiel OO, Mazariegos LEC. Prevalence and incidence of onchocerciasis as baseline data for evaluation of vector control in San Vicente Pacaya, Guatemala. Trans Royal Soc Trop Med Hyg 1982; 76: 48-53.

105. Zea FG, Hashiguchi Y, Kawabata M, Tada I, Yoshimura T, Flores CO, Recinos CMM. Guatemalan onchocerciasis: Skin snipping methods and microfilarial densities in a given minute area of the skin. Jpn J Trop Med Hyg 1980; 8: $23-32$. 